\title{
Does Tax Policy Affect Executive Compensation? Evidence from Postwar Tax Reforms
}

\author{
Carola Frydman ${ }^{\mathrm{a}}$ \\ M.I.T Sloan School of Management \\ and \\ Raven S. Molloy ${ }^{\mathrm{b}}$ \\ Federal Reserve Board of Governors
}

June 2009

\begin{abstract}
Evidence since the 1980s suggests that the level and structure of executive compensation in U.S. public corporations are largely unresponsive to tax incentives. However, the relative tax advantage of different forms of pay has been relatively small during this period. Using a sample of top executives in large firms from 1946 to 2005, we find little response of salaries, qualified stock options, long-term incentive pay, or bonuses paid after retirement to changes in tax rates on labor income - even though tax rates were significantly higher and more heterogeneous across individuals in the first several decades following WWII. To explain this lack of response, we find suggestive evidence that concerns about within-firm equality may have limited firms' ability to differentiate top executives' compensation packages based on their marginal income tax rates.
\end{abstract}

Keywords: executive compensation, tax policy

JEL Codes: G30 H24 H32 J33 J31 N32

a. Contact author. M.I.T Sloan School of Management, 50 Memorial Drive, E52-436, Cambridge, MA 02142, frydman@mit.edu b. Federal Reserve Board of Governors, $20^{\text {th }}$ \& C St, NW, Washington, DC, 20551, raven.s.molloy@frb.gov We would like to thank the staff at the Historical Collections and Danielle Barney of Baker Library for making the data collection possible. We thank Eric Engen, Adam Looney, and Robert Margo for helpful comments, and John Graham for providing his estimates of corporate income tax rates. Yoon Chang, LiJia Gong, Yao Huang, Michele McAteer, Timothy Schwuchow, James Sigel, and Athanasios Vorvis provided excellent research assistance. The views in this paper do not necessarily reflect those of the Board of Governors of the Federal Reserve System or its staff. 


\section{Introduction}

Spurred by the outsized compensation packages of top executives at a time when their firms required public funds to stay solvent, questions of whether and how the government should regulate executive pay are again in the forefront of public attention. Some critics of the current constraints on managerial pay in firms that receive government funds propose tax policy as an alternative for curbing managerial compensation. However, the empirical evidence on the effectiveness of such strategies is not compelling. Only a handful of studies have examined the influence of tax policy on managerial pay empirically, and none have found a significant effect of taxation on the level or structure of pay (Goolsbee 2000a, Hall and Liebman 2000, Rose and Wolfram 2002). ${ }^{1}$ The literature on the elasticity of taxable income of highly-paid individuals - a group that includes but is not limited to corporate executives - is also mixed (see footnote 3 ).

Using a novel dataset on top executive compensation since the 1940s, we provide new evidence on the effects of tax policy on managerial pay. Prior research on this topic has focused on the period since the $1980 \mathrm{~s}$, when low tax rates on labor income make the potential effect of taxes small and hard to identify. To obtain variation in tax rates, these studies compare highlypaid executives with those receiving a more modest paycheck. Thus, these estimates are based on the questionable comparability of individuals at very different points in the income

\footnotetext{
${ }^{1}$ Goolsbee (2000a) finds that the tax increase of 1993 led to a significant decrease in the taxable income of corporate executives, but that this decline could be almost entirely attributed to a change in the timing of stock option exercises rather than to a permanent change in behavior. However, Hall and Liebman (2000) find no evidence that tax reforms influenced stock option exercises in the 1980s. They also document that the tax advantage of stock options was relatively small in the 1980s and 1990s and that it had little effect on stock option grants at that time. Using a difference-in-difference approach, Rose and Wolfram (2002) find the rule limiting salaries to \$1 million in 1993 had only a small effect on salaries and no effect on total compensation.
} 
distribution. By contrast, labor income tax rates were much higher and varied appreciably across top executives from the 1950s to the 1970s, providing a better environment to examine the effects of tax policy.

Differences in the tax-deductibility, time deferral, and tax treatment of various forms of remuneration imply that tax policy should affect the types of compensation used to remunerate executives (Scholes and Wolfson 1992, Hall and Liebman 2000, Graham 2003). We study the effect of labor income tax rates on four major components of the compensation package: salary plus current bonus (a bonus that is paid out in the same year that it is awarded), qualified stock option grants, long-term bonuses, and bonuses paid after retirement. ${ }^{2}$ We also examine the sum of all forms of compensation that are taxable as labor income- - which we refer to as "total taxable compensation"- because tax policy may also influence total taxable earnings relative to forms of compensation that are difficult to tax, such as perquisites and private benefits.

Time-series evidence points to a strong role for tax policy in affecting executive pay: total taxable compensation was significantly lower in the 1950s and 1960s when labor income tax rates were higher, whereas the sharp increase in pay in recent decades occurred at a time of lower tax rates (see Figure 1). On the other hand, the level of taxable compensation did not significantly change after major tax reforms, suggesting that the rise in compensation over time might be driven by other factors that led to a secular rise in the incomes of the highly-paid. To account for omitted factors, our main strategy is to identify the effect of tax policy by comparing

\footnotetext{
${ }^{2}$ Due to difficulties of identification, we are mostly unable to examine the effects of capital gains or corporate income tax rates on the compensation package (see p. 6). When we do take the tax rates on these two types of income into account, the estimated effects on labor income tax rates are qualitatively similar. Throughout the rest of the paper, the term "taxes rates" refers to labor income tax rates unless otherwise specified.
} 
pre-reform to post-reform pay across executives in different tax brackets. We estimate these effects using both time-series and cross-sectional variation in changes in tax rates, using a variety of strategies to control for other factors that may confound the effect of tax changes.

For each form of compensation, we find no relationship between changes in tax rates and changes in pay. This result holds in both the entire sample and in the years from 1946 to 1972, when changes in tax rates were substantially larger and more heterogeneous across individuals. The large variation in tax rates in our sample allows us to reject statistically any meaningful effect of tax rates on all of the types of remuneration that we analyze. Thus, changes in tax rates did not have an impact on the structure of observable forms of pay at any point in time of our sample period.

We also find that changes in tax rates had a negligible effect on the total taxable labor income of executives, measured as the sum of salary, current bonus, long-term bonus payouts, and the value of exercised non-qualified stock options. We can reject an elasticity of taxable compensation with respect to taxes greater than 0.2 , a value that is on the lower end of the broad range of estimates found in the public finance literature on this topic (Lindsey 1987, Feldstein 1995, Goolsbee 1999, Gruber and Saez 2002, Saez 1999). ${ }^{3}$ These results support the conclusion

\footnotetext{
${ }^{3}$ Lindsay (1987) and Feldstein (1995) estimate a large elasticity of taxable income (between 1 and 3) by examining changes in the distribution of taxable income around the 1981 and 1986 tax reforms, but these results are potentially biased by the secular increase income inequality in those years. Gruber and Saez (2002) use panel data on individuals in the 1980 s to control for the biases imparted by inequality and mean reversion, and find that the elasticity of taxable income was about 0.6 among individuals earning more than $\$ 100,000$. However, this response is largely due to changes in tax preferences such as exemptions and itemized deductions, not to changes in earned income. Using aggregate income tax return data from 1960 to 2000, Saez (2004) estimates an elasticity of wage income in the top 1 percent between 0.4 and 1 . However, consistent with our results, he finds that high-income earners did not respond to Kennedy's large tax cuts in the early 1960s. Saez (1999) finds that the elasticity of adjusted gross income is 0.25 when identified from individuals near the boundary of a tax bracket 1979-1981.
} 
by Slemrod (1992) that there is little evidence that tax policy affects the real decisions of individuals and firms.

To analyze why changes in tax rates have no effect on the level and structure of executive compensation, we consider five possible explanations: stickiness in the compensation setting process, lack of reaction to temporary tax reforms, endogeneity of tax reforms to national economic conditions, the use of pay to provide managerial incentives, and concerns about equality within the firm. We find little support for the first four hypotheses. By contrast, changes in remuneration for each executive are strongly positively correlated with the average value of pay of the other top officers in the firm. Thus, equality concerns could help explain the lack of correlation between tax policy and executive compensation.

The rest of the paper proceeds as follows. Section 2 describes the data and estimation strategy. Sections 3 to 5 report results for three different types of compensation: salaries, qualified stock options and long-term bonus pay. Section 6 discusses the potential roles of other unobserved forms of pay, Section 7 reports results for the sum of all forms of compensation that are taxable as labor income, and Section 8 discusses possible explanations for our findings.

\section{Data description and empirical strategy}

\section{2.a. Data}

Finally, Goolsbee (1999) uses average incomes reported for different income groups in the Statistics of Income to estimate the elasticity of taxable income in reforms from the 1920s to the 1960s. His estimates for the top income group range from 0.2 to 0.7 in most reforms, but are negative for the 1935 and 1964 reforms. 
We use a panel dataset on the compensation of top executives in large publicly-traded firms from 1946 to $2005 .{ }^{4}$ The sample is based on the 50 largest publicly-held corporations in 1940, 1960, and 1990 (a total of 101 firms). ${ }^{5}$ The data from 1946 to 1991 were hand-collected from proxy statements, and from 1992 to 2005 they were obtained from Compustat's Executive Compensation database (ExecuComp). Firm-level information is from CRSP and Compustat, with some variables in the early parts of our sample collected from various editions of Moody's Industrial Manual, Moody’s Transportation Manual, and Moody’s Public Utility Manual.

Table 1 reports basic descriptive statistics of the entire dataset, which includes the five highest-paid officers in each firm in a given year. ${ }^{6}$ There are nearly 4,000 individual executives and each one is observed for an average of 6 years, giving a total of 22,000 executive-year observations (col. 1).

We focus on three types of remuneration that we can measure consistently over time: salaries plus current bonuses (bonuses awarded and paid out in the same year), the Black-Scholes value of stock option grants, and long-term incentive pay (bonuses that are received for several

\footnotetext{
${ }^{4}$ The majority of the sample (about 75 percent) is composed of manufacturing firms, with many automobile producers, airplane manufacturers and oil companies. See Frydman and Saks (2009) for a detailed description of the data collection, sample selection, and specific definitions of the variables used.

${ }^{5}$ Our analysis includes the executives in every firm for as many years as we can follow, regardless of the firm's size in that year. Thus, a concern is that the smaller firms in our sample are not representative because they are either going to become successful or are formerly successful firms in decline. However, the results presented below are robust to including only observations where the firm is ranked among the 50 largest firms in that year.

${ }^{6}$ The sample presented in Frydman and Saks (2009) used only the 3 highest-paid executives in each firm because many corporations did not disclose information on lower-paid executives prior to World War II. Since this sample focuses on the postwar period, we are able to include the $4^{\text {th }}$ and $5^{\text {th }}$ highest-paid executives. Including these executives improves the power of our estimates, but all of the results are qualitatively similar when we restrict the sample to the top 3 managers.
} 
years after they are awarded). ${ }^{7}$ We also present some evidence on bonuses paid after retirement, for which we have data through 1991. We lack the information to assess the value of other relevant forms of pay, such as pensions and perquisites, but we discuss how these forms of pay may be related to tax rates in Section 6 .

\section{2.b. Estimation strategy and identification issues}

Since many issues about identification are pertinent for all forms of pay, we follow a similar estimation strategy to evaluate the effect of tax policy on each type of remuneration.

Specifically, we regress the change in each separate type of remuneration on the change in the logarithm of one minus the marginal tax rate on labor income, which we refer to as the "net-oftax rate": 8

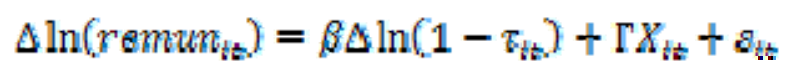

where the vector $X_{i t}$ includes individual and firm characteristics (to be described below).

Although theory predicts that changes in taxes should affect the share of compensation awarded in various forms, these specifications use the level of pay because we do not observe all of the components of total pay required to calculate the denominator (like pensions and perks). Nevertheless, our results for stock option grants and long-term bonuses are similar when we

\footnotetext{
${ }^{7}$ Although it would be useful to separate salaries from current bonus payments, many firms reported only the sum of the two prior to 1992.

${ }^{8}$ For every type of compensation except salaries, a considerable number of observations take a value of zero. Therefore, we examine the first difference of these forms of pay instead of the change in the logarithm. The distributions of these first differences are very heteroskedastic, so we trim the top and bottom 1 percent.
} 
analyze the effect of taxes on each of these forms of remuneration as a fraction of total observed pay. ${ }^{9}$

In addition to labor income tax rates, taxes on capital gains and corporate income also alter the tax incentives for different components of the compensation package (Scholes and Wolfson 1992, Hall and Liebman 2000). Therefore, a thorough analysis of how tax policy affects compensation decisions should have a broad perspective that takes into account the implications of all types of taxes for both the employer and the employee. However, assessing the effects of capital gains and corporate income tax rates in our data is difficult. These rates changed infrequently during our sample period and when they did change they usually changed at the same time, making identification of their separate effects based on time series problematic (see Figure 2). ${ }^{10}$ Using cross-sectional variation to identify the effects of these rates is also problematic. First, there is no cross-sectional variation in the marginal capital gains tax rate, as all executives faced the same rate. In addition, there is little cross-sectional variation in the corporate income tax rate in the large firms included in our sample. Prior papers have estimated cross-sectional differences in corporate tax rates from cases in which firms have negative earnings or can take advantage of tax-loss carryforwards (Hall and Liebman 2000, Plesko 2003).

\footnotetext{
${ }^{9}$ We focus on options and incentive pay because salary plus current bonus was close to 100 percent of total observed pay for many executives in the earlier decades of our sample.

${ }^{10}$ These caveats notwithstanding, we find no appreciable effects of changes in capital gains or corporate income tax rates when we include the top marginal rates in any specification. Moreover, including these rates does not alter the estimated effect of labor income tax rates. Instead of estimating the effects of all 3 tax rates separately, an alternative strategy that incorporates all 3 tax rates is to compute the tax burden to the executive of each form of pay for a given post-tax cost to the company (Hall and Liebman 2000). We have applied this methodology to analyze qualified stock option grants relative to salaries from 1947 to 1972, a tradeoff with considerable tax implications due to the large discrepancy between tax rates on labor income and capital gains. We find that the ratio of these two forms of pay was unrelated to changes in their relative tax advantages, suggesting that our analysis of labor income tax rates is not biased by excluding capital gains and corporate income tax rates.
} 
However, these outcomes are rare in our sample. For example, more than 95 percent of the firms in our sample from 1950 onward - the period for which the corporate income data are available-report pre-tax income more than 10 times the cutoff for the maximum corporate income tax rate. ${ }^{11}$

By focusing on the changes in pay and taxes rather than on the levels of these variables, estimating equation (1) mitigates many person-specific omitted factors that would bias our estimates. Still, due to the progressive structure of tax policy, the change in the tax rate faced by an executive will reflect other changes in his or her income beyond those induced by changes in tax policy. In particular, if individuals endogenously alter their behavior in response to the marginal tax rate of each tax bracket, the observed change in tax rates will not reveal the exogenous effect of the change in policy. To solve this problem, we calculate the change in tax rates in year $t$ as the rate an individual would have faced had his or her income been the same as it was in the previous year (Gruber and Saez 2002).

We calculate an executives' marginal income tax rate assuming that his income is equal to the total compensation paid by his firm that is taxable as personal labor income (defined as salary + current bonus + payouts from long-term incentive programs + the value of exercised nonqualified stock options) and that he files jointly with a spouse. Unobserved sources of household income and tax deductions make this estimate an imperfect approximation of the actual marginal rate face by an individual. However, microdata from the Statistics of Income (which are

\footnotetext{
${ }^{11}$ Using a more sophisticated approach, Graham $(1996,2007)$ uses dynamic information on both net operating loss carrybacks and carryforwards to calculate firms' tax rates from 1980 to 2005. His data confirm the lack of crosssectional variation in corporate income tax rates in our sample: For the firms in our sample that we can match to Graham's estimates, 84 percent of Graham's estimates are within 1 percentage point of the maximum corporate rate.
} 
available from 1960 onward) suggest that the measurement error in our estimate of tax rates is relatively small. $^{12}$

Table 2 shows the distribution of changes in the net-of-tax rate in every year of our sample in which tax rates changed. In the first half of the sample, a number of tax reforms led to significant changes in the net-of-tax rate. In spite of being among the highest-paid individuals in the economy, the tax system was so progressive that many of these executives were in different tax brackets. ${ }^{13}$ Thus, there is considerable variation in tax rates across individuals during most of these reforms, which allows us to precisely estimate the effect of changes in tax rates. By contrast, all executives were in the top income bracket after 1971, and the changes in tax rates after that year were much smaller. Therefore, the earlier part of our sample is a more natural environment to look for an effect of tax policy on executive pay.

We estimate equation (1) pooling the data from all years in a single regression and controlling for each executive's initial taxable compensation. ${ }^{14}$ Thus, we identify the effect of tax rates by comparing two executives with similar levels of compensation but at two different points in time — one prior to one reform and the other prior to a different reform — such that they

\footnotetext{
12 Specifically, we match the executives in our sample in 1960, 1970, 1980, 1990, and 2000 to individuals in the SOI data who report a similar amount of wage income. For 1980 to 2000 we compute an "SOI tax rate" as the average reported marginal income tax rate in the SOI data among individuals with similar wage income. For 1960 and 1970 (when marginal tax rates are not reported) the SOI tax rate is the marginal income tax rate implied by the level of total taxable income reported in the corresponding SOI data. In each year, the correlation of our estimated tax rate based on executive compensation and the SOI tax rate is greater than 0.98.

${ }^{13}$ Prior to 1972 , differences in the marginal tax rate between adjacent tax brackets were relatively small, especially at higher income levels (the tax rate was a concave function of income). However, the large number of narrow brackets created substantial differences in marginal tax rates among highly-paid individuals.

${ }^{14}$ Gruber and Saez (2002) account for mean reversion by controlling for a nonparametric function of income in addition to $\ln$ (income). Our results are similar when we control for lagged compensation in a similar manner, but we report specifications with only $\ln$ (income) for simplicity.
} 
faced different changes in tax rates due to the different reforms. This strategy controls for mean reversion in income, which causes higher-income executives to experience larger reductions in labor income, thereby leading to a systematic relationship between the predicted change in tax rates and the change in pay even if there is no true effect of tax policy (Gruber and Saez 2002).

Estimating a single regression over the entire sample period is also appealing because it generates more variation in changes in tax rates than can be obtained from any single reform. However, results based on comparisons over time might be misleading if omitted factors that evolve over time, such as income inequality or corporate governance, are correlated with both tax policy and changes in compensation. Therefore, we also estimate specifications that include year fixed effects on a sample ending with the 1969 reform (which enacted a series of changes in marginal income tax rates through 1972), since there is no cross-sectional variation in changes in tax rates after that time. We find similar results using either specification. ${ }^{15}$

\section{The Effect of Taxes on Salary and Bonus}

We start by examining the relationship between tax rates and the logarithm of salaries plus current bonuses (which we will refer to as "salaries"). ${ }^{16}$ As shown in column 1 of Table 3 , there is no meaningful relationship between changes in taxes and salaries when we look at the simple

\footnotetext{
${ }^{15}$ A third estimation strategy would be to estimate the regression for each separate tax reform. However, we cannot implement this strategy for post-1971 data because tax rates do not vary across the executives in our sample. Moreover, it is difficult to control for mean reversion in such a specification because doing so reduces the variation in tax rate changes substantially. For example, the standard deviation of the $\ln$ (net-of-tax rate) is 0.042 in our entire sample after controlling for year fixed effects. However, it falls to 0.022 when also controlling for the logarithm of income interacted with the year fixed effects.

${ }^{16}$ Most firms only report the sum of salaries and current bonuses prior to 1992, so we cannot examine these two forms of pay separately.
} 
correlation of these two variables with minimal controls; the coefficient on the net-of-tax rate is small, and we can reject an elasticity greater than 0.17 with 95 percent confidence. Controlling for mean reversion in compensation (col. 2) does not alter this result.

A potential source of bias in these estimates is that the secular trend in income inequality might be correlated with changes in tax rates over time (Slemrod 1996). ${ }^{17}$ We address this issue in two ways. First, we include a cubic time trend to account for smooth changes in income inequality during our sample period. By interacting this trend with lagged income, we allow the effect of inequality on changes in salaries to vary with the level of income (col. 3). Second, we include a direct measure of inequality: the share of aggregate wages and salaries earned by the $95^{\text {th }}$ to $99^{\text {th }}$ percentile of the income distribution in the previous year computed by Piketty and Saez (2003). We also control for general economic prosperity by including the growth rate in real GDP. Following Goolsbee (2000b), we allow the effects of inequality and economic prosperity to vary with the level of income by including interactions of these variables with lagged income (col. 4). None of the controls for inequality and economic conditions alter the estimated effect of taxes on salaries. Even including all of these variables in the same specification (col. 5), the estimated effect of taxes remains small and we can confidently reject an elasticity greater than 0.2 .

Finally, we control for omitted factors that might be correlated with changes in tax policy over time by including year fixed effects in the regression. The sample period is limited to 19471972 because we do not have cross-sectional variation in tax rates after that period. Another

\footnotetext{
${ }^{17}$ Slemrod (1996) shows that an apparent effect of taxes on the income of the rich during the Revenue Act of 1986 disappears when directly controlling for a measure of income inequality.
} 
advantage of examining this period separately is that income inequality did not change dramatically at that time (Piketty and Saez 2003). As shown by columns 6-8, neither changing the sample period nor including year fixed effects leads us to find that changes in salaries were related to changes in income tax rates.

In summary, we find no evidence that changes in salaries and current bonuses were related to tax policy. A possible explanation for this result is that salaries adjust slowly over time to changes in tax rates. However, we still find no relationship between changes in taxes and salaries when we allow taxes to have an effect up to 5 years after a tax reform.

\section{The Effect of Taxes on the Use of Qualified Stock Options}

In recent years, employee stock options have become an important component of an executive's compensation package (Hall and Liebman 1998). Since the 1980s, most options granted have been taxed as labor income and, therefore, have had only minor tax advantages relative to cash compensation. ${ }^{18}$ Perhaps due to the small size of this tax advantage, tax policy has had at most a minor role on use of stock options during this period (Goolsbee 1999, Hall and Liebman 2000, Katsucak 2005).

In contrast to the options that are prevalent today, the majority of employee stock options granted in the 1950s and 1960s were "qualified" or "restricted." As such, these options were untaxed on both the grant and the exercise date, while the appreciation on shares acquired with

\footnotetext{
${ }^{18}$ For most of our sample period, the gains from non-qualified stock options (i.e. options that are not Incentive Stock Options) were taxed as personal income at the time they are exercised and future appreciation on the shares purchased with these options were taxed as capital gains. Thus, these options had an advantage relative to cash compensation because of the deferral of the tax payment.
} 
these options was taxed as capital gains. The 1950 Revenue Act introduced qualified stock options and their use became relatively common over the following 20 years (Frydman and Saks 2009). ${ }^{19}$ Given the large differences between the marginal tax rates on labor income and capital gains at that time (see Figure 1), this type of remuneration had a substantial tax advantage relative to other forms of pay. ${ }^{20}$ Subsequent tax reforms in the 1960s and 1970s reduced the tax advantage of options by lowering labor income tax rates and imposing more stringent requirements on the attributes of qualified options. The granting of qualified stock options was banned from 1976 to 1981, and has been subject to a stringent cap since then. Thus, the vast majority of options granted since the mid-1970s have been non-qualified, and consequently have been taxed as labor income. Therefore, we focus our analysis on the period from 1950 to 1975 , when the large tax advantage of options - as well as large changes in this advantage resulting from tax reforms - make the prospect of finding an effect of tax policy on the use of employee stock options more promising.

We test for an effect of changes in tax rates on stock option grants by estimating changes in the value of qualified options granted to each executive as a function of changes in his or her netof-tax rate. ${ }^{21}$ As in the previous specifications, we include controls that may be related to the award of stock options. As shown in column 1 of Table 4, there is no statistically significant effect of changes in labor income tax rates on the value of qualified stock option grants for the

\footnotetext{
${ }^{19}$ Prior to 1950 , stock options were granted to executives occasionally, but were not an attractive means of compensation because they were likely to be taxed as income and marginal tax rates on labor income were extraordinarily high (Washington and Rothschild 1951).

${ }^{20}$ Using the method of Hall and Liebman (2000), the average tax advantage of granting qualified stock options in our sample was \$59 for every \$100 of cash salaries from 1950 to 1955.

${ }^{21}$ We use the Black-Scholes formula to value stock option grants.
} 
1951 to 1975 period. Our results are unchanged if we include year fixed-effects to control for any year-specific omitted factors that might be correlated with changes in tax rates and qualified stock option grants (col. 2). ${ }^{22}$ We can reject with 95 percent confidence that a 1 -standard deviation increase in the net-of-tax rate would reduce the value of qualified stock option grants by more than $\$ 10,000$ (equivalent to less than $1 / 15$ of a standard deviation of the changes in the value of stock option grants in this sample). ${ }^{23}$

Because employee stock options were generally granted only once every few years to each executive during this sample period, using annual changes in option awards may underestimate the effect of changes in tax policy. To address this problem, we estimate the same specification for the average value of options granted over a three-year period. ${ }^{24}$ While the estimated effect becomes slightly larger, it remains insignificant and we can still reject an effect of a 1-standard deviation change in tax rates that is greater than $\$ 10,000$ (cols. 3 and 4). Thus,

\footnotetext{
${ }^{22}$ Results are similar if we exclude lagged income to increase the variation of changes in tax rates within a year.

${ }^{23}$ An alternative strategy would be to assess if executives facing larger labor income tax rates received more options when they were first introduced by the 1950 reform. However, since tax rates are determined by an individual's income level, they are likely correlated with many other unobservable factors (such as productivity) that also affect the use of stock options. Because very few options were granted before the reform, we cannot use the pre-reform correlation of taxes and stock options to account for this bias. With these caveats, we find no evidence that executives facing higher tax rates received more options during the five years after the 1950 reform.

${ }^{24}$ Specifically, the dependent variable is the 3 -year change in the average value of qualified options granted in the past 3 years. The sample size shrinks significantly because it is limited to executives who remain in the sample for a longer period of time and because the sample does not begin until 1955 (the first year for which the 3-year change in the 3-year average of option grants includes only years in which qualified options were allowed). The sample for the fixed-effects specification ends in 1974 (instead of 1972 as in col. 2) because the 3-year change in tax rates varies across individuals in 1973 and 1974. Standard errors are a bit smaller when we cluster by executive to account for serial correlation in the 3-year changes, but the estimated effect of taxes is still not significantly different from zero.
} 
we conclude that the use of options was not affected by tax policy, even during a period when qualified stock options had a significant tax advantage over other forms of pay. ${ }^{25}$

\section{The Effect of Taxes on Long-Term Incentive Pay}

Although it is also taxed as labor income, long-term incentive pay-bonuses that are paid out in either cash or stock for a fixed number of years after they are awarded — has a tax advantage relative to salaries and current bonuses at times of high labor income tax rates because the tax payment is deferred until the award is received. ${ }^{26}$ In addition, by smoothing a bonus payment over time, some executives can avoid moving into a higher tax bracket, thereby increasing their total after-tax compensation.

Due to these advantages, we would expect executives who face higher marginal tax rates on labor income to receive more long-term bonuses. Ideally, we would examine changes in bonus awards as a function of changes in taxes. However, information on awards is not available in ExecuComp and much of the hand-collected data prior to 1992 only provide information on the amounts paid out for bonuses awarded in previous years. Consequently, we examine the correlation of tax rates with long-term bonus payouts. About 77 percent of the bonuses for which we have information on the payout structure are paid out within four years.

\footnotetext{
${ }^{25}$ This result corroborates the evidence shown in Frydman and Saks (2009) that the use of stock options in the 1950s ad 1960s was not as widespread as expected given the sizable tax advantage of qualified options.

${ }^{26}$ On the other hand, deferred cash pay is tax disadvantaged relative to salaries because current remuneration can be deducted from corporate income immediately whereas deferred bonuses are not considered an expense until they are paid out.
} 
Thus, we analyze the change in the payout after two, four and six years to allow enough time for changes in tax policy to affect bonus payments.

Table 5 reports the relationship between changes in bonus payments and changes in the net-of-tax rate. ${ }^{27}$ Whether we exploit time-series variation in tax rates or we include year fixed effects in the regression, we find no evidence that a lower net-of-tax rate (higher taxes) led to larger long-term bonus awards. ${ }^{28}$ Even in the specification with the most negative coefficient and largest standard error (col. 5), we can reject that a 1-standard deviation decrease in the netof-tax rate leads to an increase in long-term bonus pay of more than $\$ 30,000$ (which is less than $1 / 8$ of the standard deviation of the change in long-term bonus pay). However, these estimates should only be taken as suggestive because they are based on cumulative payouts over time instead of bonus awards. ${ }^{29}$

\section{Other Forms of Pay: Pensions and Perks}

Many other types of compensation that we do not observe are not taxed as labor income when they are awarded. It is possible that substitution into these other forms of pay responded to changes in tax rates, even though observed forms of pay did not. Thus, our analysis may underestimate the effect of taxes by only including some components of pay. Two main

\footnotetext{
${ }^{27}$ We continue to report standard errors clustered by year because clustering by individual to account for serial correlation leads to smaller standard errors.

${ }^{28}$ These results are based on trimming the top and bottom 3 percent of changes in long-term bonus pay. When we trim only the top and bottom 1 percent, we find statistically significant—but small — negative coefficients on the netof-tax rate. However, we do not present these results because they are driven by a very small fraction of our sample.

${ }^{29}$ Nevertheless, we find no evidence that changes in bonus awards are related to changes in tax rates in the small sample for which information on awards is available.
} 
unobserved forms of pay that we are particularly concerned about are retirement benefits and perquisites.

For a given tax rate on corporate income, pensions are tax-advantaged at times of high personal income tax rates since executives are not taxed until retirement, when they usually drop down to a lower income tax bracket. In fact, experts on executive compensation in the 1950s and 1960s frequently mentioned high taxes as a reason for the expansion of executive pension plans (NICB 1953, Patton 1961, Smyth 1960). We do not have enough information to analyze the pensions of the executives in our sample. ${ }^{30}$ However, aggregate data do not provide strong support for the role of taxes in driving general pension use. The Bureau of Economic Analysis estimates that employer contributions for employee pension and insurance funds (which includes all employees — not just executives) rose from 2 percent of wages and salaries in the late 1940s to 13 percent in 1977 and then fluctuated between 13 and 16 percent from 1977 to $2008 .^{31}$

Moreover, evidence from prior research suggests that the value of pensions for top executives as a fraction of their total pay was likely not much lower in recent years than it was in the 1960s. ${ }^{32}$ Thus, pensions did not decrease as their tax advantage diminished over time.

A type of post-retirement compensation that we do observe in our data is bonuses that are paid after retirement. The fraction of executives receiving these bonuses rose from near zero in

\footnotetext{
${ }^{30}$ Proxy statements present descriptions of retirement plans, but an assessment of their value for each individual would require information that we lack, such as the executive's age, tenure, and salary prior to retirement.

${ }^{31}$ Data are from lines 3 and 7 of Table 2.1 of the National Income and Product Accounts.

${ }^{32}$ Lewellen (1968) reports that retirement benefits were 15 percent of after-tax total pay from 1950 to 1963. Because pensions were taxed at a lower rate than labor income, their value relative to total pre-tax pay must have been even lower than 15 percent. By contrast, Sundaram and Yermack (2006) find increases in the actuarial value of pensions to be about 10 percent of total CEO pay from 1996 to 2002, and Bebchuk and Jackson (2005) report that the ratio of executives' retirement benefits to total pay received during their entire service as CEO was 34 percent in 2004.
} 
the 1940 s to 25 percent in the 1960 s and then fell back to 12 percent from the mid-1970s to 1990 (ExecuComp did not record these bonuses so we cannot observe them post-1991). To assess the correlation of these bonuses with tax rates, we regress the change in the dollar value of the retirement bonuses awarded to each executive as a function of the change in their net-of-tax rate. There is no relationship between these two variables in the full sample (col. 1 of Table 6) or when the sample is limited to 1947-1972, the years when the historical record suggests that tax policy spurred deferred pay (col. 2). We find a small effect when we include year fixed effects (col. 3), but the estimated coefficient has the wrong sign: executives facing larger tax cuts get larger increases in retirement bonuses. ${ }^{33}$ We also find no effect if we examine changes in the 3year average value of retirement bonus awards, which reduces volatility of bonus awards and allows taxes to have a delayed effect.

Perquisites and other private benefits are other likely candidates for remunerating executives when tax rates are high. Even though the Internal Revenue Code of 1954 included fringe benefits as taxable income, the IRS was unable to enforce taxes on perquisites because of a lack of information about these benefits (McGahran 1988). The SEC's disclosure requirements changed in 1978 to include perks over a minimum threshold, but data on perks have been sparse even after this date for several reasons. First, perks were only reported in a category that also included many other forms of remuneration, such as income from incentive and profit sharing plans. In addition, the SEC raised the minimum threshold of disclosure in 1983, and most firms stopped reporting this category of compensation. Following an extensive revision of disclosure

\footnotetext{
${ }^{33} \mathrm{We}$ also find no correlation of changes in tax rates with changes in the logarithm of retirement bonus awards, indicating that the magnitude of these awards does not depend on tax rates.
} 
requirements in 1992, perks were reported in an "Other Annual Compensation" category that included other forms of remuneration (albeit fewer kinds of pay than before) such as preferential gains on pay deferred by the executive. ${ }^{34}$ Although the information improved since 1992, its accuracy is still questionable. ${ }^{35}$

Due to these data issues, the only way to gauge the value of perks awarded to the executives in our sample is to look at "other compensation," for which we have values from 1978-1981 and 1993-2005. The median value of this category of pay relative to total taxable compensation was about 3 percent in the earlier period (when the top marginal tax rate was 50 percent) and less than 1 percent in the later years (when the top marginal tax rate was between 35 and 40 percent). These statistics are consistent with the idea that perks were higher when tax rates were higher, although the evidence is not strong because more forms of pay were included in the "other compensation" category in the early period. Moreover, the magnitude of "other compensation" in the earlier period is too small to offset the large difference in tax rates between the two periods. In addition, we find no effect of the 2003 tax reform on this measure of "other compensation," suggesting that perks do not necessarily respond to changes in taxation. ${ }^{36}$

\footnotetext{
${ }^{34}$ In addition, the amount and type of individual perquisites or other personal benefits exceeding 25 percent of total perks had to be identified in a footnote (Loss and Seligman 2003). However, ExecuComp does not report this information.

${ }^{35}$ Most research has focused on whether a certain perk was offered rather than on its actual value (Rajan and Wulf 2006, Yermack 2006).

${ }^{36}$ Our ability to analyze the 2003 tax reform is rather limited because of the lack of cross-sectional variation in tax rates at the top of the income distribution. Using the entire ExecuComp sample, we find that "other compensation" increased from 2002 to 2004, even though the reform reduced tax rates. In addition, in a sample of executives justunder and just-above the cutoff for the top marginal tax rate, changes in other compensation from pre- to postreform are unrelated to changes in tax rates.
} 
In summary, it is difficult to assess whether the introduction of pensions or perks earlier in the century was spurred by the high tax rates at that time. However, the available evidence suggests that these forms of pay were unrelated to tax policy in subsequent years: these benefits did not materially decrease as their tax advantages diminished, and differences across individuals were not correlated with tax rates. It is possible that firms did not optimally tailor these forms of compensation to take advantage of the tax system because their tax implications were difficult to fully comprehend and benefit plans tended to change only infrequently (Patton 1961). Moreover, changes in the values of pensions and perks were likely too small to compensate for the large changes in taxes over time.

\section{The Effect of Taxes on Total Taxable Compensation}

Finally, we combine the different forms of remuneration discussed above to examine the effect of tax policy on an executive's total taxable compensation. This analysis is similar in spirit to the literature on the elasticity of taxable income (Slemrod 2000). While there has been extensive debate on the magnitude of the elasticity in recent decades (Lindsey 1987, Feldstein 1995, Feenberg and Poterba 1993, Slemrod 1996, Saez 2004, Gruber and Saez 2002), the few papers examining earlier decades have found little response of top incomes to tax rates (Goolsbee 1999, Saez 2004).

As discussed in Section 2, the compensation that is taxable as labor income is the sum of salary, current bonus, long-term bonus payouts, and the value of exercised non-qualified stock options. Although an executive's remuneration is not the only form of income he or she receives 
in a year, our measure of taxable compensation is highly correlated with taxable income reported in the SOI data. ${ }^{37}$

Table 7 reports the results of regressing the change in the logarithm of taxable compensation on the change in the logarithm in the net-of-tax rate. We use the same specifications as in Section 3 to control for mean reversion and income inequality. In no case do we find a statistically significant effect of the net-of-tax rate, and we can easily reject an elasticity of taxable compensation with respect to the net-of-tax rate greater than 0.2 . We also find no effect if we allow changes in tax rates to take up to 5 years to affect compensation by including lagged changes in the net-of-tax rate (results not shown). These results are consistent with the negligible effect of tax rates found by Goolsbee (1999) for tax reforms prior to 1986, using both the income share of high earners (based on aggregate data from tax records) and executive compensation micro-data during the 1971-72 and 1935 tax reforms.

Our estimates suggest that the average elasticity of taxable income over the entire postwar period is small. We also find no effect prior to the 1970s, but it is possible that the taxable income of executives may have been more sensitive to tax policy in recent years. We cannot apply our methodology to the recent period because all executives in our sample face the same tax rate in each year after 1972. However, when we interact the change in tax rates with either a linear time trend or a post-1980 dummy variable, none of the specifications shown in

\footnotetext{
${ }^{37}$ Matching the individuals in our sample in $1960,1970,1980,1990$, and 2000 with individuals with similar wages in the SOI microdata, the correlation of our estimate of taxable compensation with taxable income in the SOI data is greater than 0.94 in every year.
} 
columns 1 to 5 of Table 7 indicate that the effect of taxes was any different in the second half of our sample.

\section{Explaining the Lack of Relationship between Compensation and Tax Rates}

In summary, we have found no evidence that changes in tax rates appreciably affect the level or structure of executive compensation. This result holds for the entire sample as well as for the period from 1947 to 1972, when there was much more variation in labor income tax rates at the top of the income distribution than in more recent decades. Our estimates of the correlation between tax rates and compensation are precise enough to rule out that these results are due to noise in the data.

Our results are surprising because tax policy made some forms of pay substantially more advantageous relative to others during most of the postwar period. Moreover, our sample of large firms is a natural group in which to expect tax policy to have noticeable effects on the composition of pay because executives in large firms were taxed at very high rates due to their high incomes. ${ }^{38}$ In addition, large firms tend to be trendsetters in compensation policy (Ellig 2002), so we expect the adoption and use of new forms of pay in response to changes in tax policy to emerge first in large corporations. To understand why firms did not alter pay in response to tax reforms, we investigate five potential explanations.

First, the pay of each individual could change very slowly over time if there is rigidity or hysteresis in the compensation setting process. However, stickiness in pay does not appear to be

\footnotetext{
${ }^{38}$ We do not find any meaningful interactions between changes in tax rates and firm size, suggesting that the effect of taxes is similar in the large and small firms in our sample.
} 
a first-order explanation for our findings given that we found no effect of taxes on the changes in compensation even after 5 years. Nevertheless, we test this hypothesis more directly by including lagged changes of the dependent variable in a regression for each component of pay. If compensation policy evolves slowly over time, changes in pay should be positively serially correlated (for example, firms that grant stock options in one year would be likely to make similar grants the next year). We find no evidence of positive serial correlation in the changes of any type of remuneration except for long-term bonus payouts, which by design are strongly positively correlated from year to year (Panel A of Table 8). ${ }^{39}$ Changes in stock option grants are negatively serially correlated, highlighting the fact that stock option grants were very lumpy prior to the 1980s and each executive tended to receive a grant only once every few years. ${ }^{40}$ Another source of stickiness that might limit the responsiveness of compensation to tax rates is downward nominal rigidity. However, we find no evidence that salaries respond more to tax cuts (which should result in salary increases) than to tax increases (which should result in salary decreases).

A second explanation for the absence of correlation between changes in executive pay and tax rates is that some tax reforms were intended by legislators to be temporary. Firms may choose not to respond to transitory changes in taxes if the cost of altering the compensation package for a brief period is sufficiently high. Using the narrative analysis of postwar tax

\footnotetext{
${ }^{39}$ Table 8 reports results from specifications with year fixed effects, but results are similar for the other specifications discussed throughout the paper for each type of pay.

${ }^{40}$ After controlling for serial correlation in each form of pay, we find a puzzling result that increases in the net-oftax rate (tax cuts) are associated with a drop in salaries and an increase in long-term bonus pay, the opposite of what would be predicted by their relative tax advantages.
} 
changes of Romer and Romer (2008), we repeat our estimation for each type of pay assuming that no change in taxes occurred in tax reforms that they identify as temporary. However, we find no correlation of the permanent changes in tax rates with any component of executive pay (Panel B of Table 8).

A similar concern is that some tax reforms are endogenous to changes in national income and the state of the economy, which might bias the estimated effect of tax rates on executive pay. Therefore, we repeat our estimation for each type of pay assuming that no change in taxes occurred in tax reforms that Romer and Romer (2008) identify as endogenous. Even in this case, the correlation of the exogenous changes in tax rates (which are a subset of the permanent changes) with any component of executive pay is negligible (Panel C of Table 8).

A fourth reason why executive pay may be unresponsive to changes in tax rates is that compensation might be primarily determined by the provision of managerial incentives as in a standard principal-agent model, leaving little scope to alter pay for other reasons. However, the correlation between an executive's wealth and the performance of the firm is driven mostly by his holdings of stock and stock option, rather than by annual changes in salaries, bonuses, stock option grants, or the other components of the compensation package (Hall and Liebman 1998, Frydman and Saks 2009). In addition, our results partly account for this mechanism because our specifications control for the executive's initial stock holdings relative to shares outstanding. However, we assess this explanation more directly by controlling for the correlation between wealth and firm performance, measured by the executive's dollar gain in stock and stock option wealth from a 1 percent increase in form performance (following Core and Guay 1999). 
Changes in each form of pay are not appreciably related to the sensitivity of wealth to performance, and these controls do not alter our estimates for the changes in labor income tax rates (Panel D of Table 8). Thus, incentive provision does not seem to explain our findings.

A fifth explanation for our results is that concerns about equality within the firm may have limited firms' ability to differentiate executives' compensation packages. These concerns may have driven firms to preserve internal differences in the pre-tax level of pay by giving similar changes in compensation to all executives, regardless of each individual's marginal income tax rate. We test this theory by including in our basic specification the change in the average value of each type of remuneration awarded to the other 4 highest-paid officers of the firm. In each case, this coefficient is positive, significant, and economically meaningful (Panel E of Table 8). For example, an executive's increase in stock option grants is $\$ 87,000$ larger (about $1 / 2$ a standard deviation) when the average value of others' stock option grants rises by $\$ 191,000$ (1 standard deviation).

More generally, firm fixed effects explain about 55 percent of the variation in changes in salaries within a year, suggesting that firm-specific factors are extremely important in determining pay. Historical accounts also support the notion that equality within the firm mattered. For example, Arch Patton — one of the best-known management consultants of the post-World War II era (New York Times Nov. 30 1996) — stated that in the 1960s and 1970s "the compensation of upper-echelon positions moves in lockstep, like soldiers in a parade.” (1994).

While our findings are suggestive of the importance of equality concerns in compensation arrangements, the positive correlation of own pay with other officers' compensation could be 
driven by omitted firm-specific factors. For example, firms may increase the pay of all their executives if the future prospects of the firm improve, or alter the structure of compensation if they are highly levered. The regressions in Panel E of Table 8 include firm-level controls for the initial level and change in firm performance (rate of return), size (market value, assets, and sales), growth opportunities (market-to-book ratio), and book leverage (total liabilities to assets). However, the correlation of own pay with others' pay could still reflect unobserved characteristics of the firm. $^{41}$

The importance of within-firm equality in compensation arrangements might be a particular feature of the 1950s and 1960s, when social norms were plausibly less tolerant of income differentials (Piketty and Saez 2003, Levy and Temin 2008). Using our entire sample (without year fixed effects) and interacting others' pay with a post-1980 dummy variable, the correlation of salary plus current bonus with others' salaries did not change over time. By contrast, the correlations of stock option grants (including non-qualified options) with others' grants and of long-term bonus payouts with others' payouts are only about half as large in the later years as they were prior to the 1980 s (and these differences are significant). ${ }^{42}$ Thus, it appears that for incentive compensation the influence of others' pay has diminished over time, but that salary structures still played an important role even in the 1980-2005 period. ${ }^{43}$

\footnotetext{
${ }^{41}$ Even though concerns about equality might limit variation in pay within the firm, we still might expect to see differences in pay across firms that are related to top executives' tax rates. We find no evidence of such an effect, but it is possible that equality within the entire firm - and not just within the top management - is important, which implies that the tax rates faced by the top 5 officers are not the relevant tax rates for examining pay differentials across firms.

${ }^{42}$ We cannot examine how this correlation changed over time for retirement bonuses because we do not have data on these bonuses after 1992.

${ }^{43}$ The estimated effect of tax rates did not change after 1980 in any of these specifications.
} 


\section{Conclusion}

Using a novel dataset on top executive compensation in the entire post-war era, we find little response of executive salaries, bonuses (both short-term and long-term), and stock option grants to changes in labor income tax rates. In contrast to previous studies of executive pay that focus on the period since the $1980 \mathrm{~s}$, the historical data provide much larger variation in tax rate changes both across individuals and over time with which to identify the effect of tax policy. Because our results are precisely estimated, we can rule out any meaningful response of the forms of executive pay that we observe to changes in tax rates. A strong within-firm correlation of all components of pay suggests that concerns about equality within the firm prevented firms and their executives from taking advantage of tax incentives in a way that theory would suggest.

Our results do not imply that tax policy has not affected any aspect of executive pay. For example, high tax rates in the 1950s and 1960s might have spurred the adoption of pensions, perks and qualified stock options, even though the use of these benefits did not decrease as their tax advantage diminished over time. Tax policy also appears to influence the choice between qualified and non-qualified stock options (Hite and Long 1982, Madeo and Omer 1994, Austin, Gaver and Gaver 1998). Tax reforms have sometimes altered the timing of when executives receive bonuses and exercise stock options (Goolsbee 2000a, US Bureau of Economic Analysis 1993), and the degree of personal tax savings has influenced the backdating of option exercises (Dhaliwal, Erickson and Heitzman 2008). 
In addition to effects on compensation, the tax incentives of different forms of pay can affect other aspects of corporate financial policies. For example, firms that can deduct large amounts of compensation from corporate income have a smaller incentive to use debt as a tax shield (DeAngelo and Masulis 1980). On the other hand, the economic magnitude of the effect of tax policy on corporate financial decisions tends to be small (Graham 2003). Thus, our analysis provides additional evidence that tax policy has only a limited effect on the real decisions of firms and their executives (Slemrod 2000), suggesting that simply altering tax rates may not be a very effective mechanism to regulate executive pay.

\section{Acknowledgements}

We would like to thank the staff at the Historical Collections and Danielle Barney of Baker Library for making the data collection possible. We thank Eric Engen, Adam Looney, and Robert Margo for helpful comments, and John Graham for providing his estimates of corporate income tax rates. Yoon Chang, LiJia Gong, Yao Huang, Michele McAteer, Timothy Schwuchow, James Sigel, and Athanasios Vorvis provided excellent research assistance. The views in this paper do not necessarily reflect those of the Board of Governors of the Federal Reserve System or its staff.

\section{References}

Austin, Jeffrey R., Jennifer J. Gaver, and Kenneth M. Gaver. 1998. "The Choice of Incentive Stock Options vs. Nonqualified Options: A Marginal Tax Rate Perspective," Journal of the American Taxation Association (20): 1-21.

Bebchuk, Lucian Arye and Robert J. Jackson. 2005. "Executive Pensions," Journal of Corporation Law, Vol. 30, No. 4: 823-855

Dhaliwal, Dan, Merle Erickson and Shane Heitzman. 2008. "Taxes and the Backdating of Stock Option Exercise Dates," Working paper.

DeAngelo, H and R. W. Masulis. 1980. "Optimal Capital Structure under Corporate and Personal Taxation," Journal of Financial Economics (8): 3-29. 
Feenberg, Daniel, and James Poterba. 1993. "Income Inequality and the Incomes of the VeryHigh-Income Tax Payers.” In Tax Policy and the Economy, edited by James Poterba, vol. 7 Cambridge, MA: MIT Press.

Feldstein, Martin. 1995. "The Effect of Marginal Tax Rates on Taxable Income: A Panel Study of the 1986 Tax Reform Act." Journal of Political Economy, Vol. 103(3), June: 551-72

Frydman, Carola, and Raven E. Saks. 2009. "Executive Compensation: A New View from a Long-Term Perspective, 1936-2005.” Working Paper, MIT.

Goolsbee, Austan. 1999. "Evidence on the High-Income Laffer Curve from Six Decades of Tax Reform." Brookings Papers on Economic Activity: 1-64.

Goolsbee, Austan. 2000a. "What Happens When You Tax the Rich? Evidence from Executive Compensation," Journal of Political Economy, Vol. 108(2), April.

Goolsbee, Austan. 2000b. "It's Not About the Money: Why Natural Experiments Don't Work on the Rich." In Does Atlas Shrug? The Economic Consequences of Taxing the Rich, edited by Joel B Slemrod, New York, NY: The Russell Sage Foundation.

Graham, John R. 1996. "Proxies for the corporate marginal tax rate," Journal of Financial Economics 42: 187-221

Graham, John R. 2003. "Taxes and Corporate Finance: A Review," Review of Financial Studies 16: $1074-1128$.

Graham, John R., and Lillian Mills. 2007. "Simulating Marginal Tax Rates Using Tax Return Data," Journal of Accounting and Economics, forthcoming

Gruber, Jon and Emmanuel Saez, 2002. 'The Elasticity of Taxable Income: Evidence and Implications," Journal of Public Economics 84: 1-32.

Hall, Brian J. and Jeffrey B. Liebman. 1998. “Are CEOs Really Paid like Bureaucrats?” Quarterly Journal of Economics 113 (August): 653-691.

Hall, Brian J. and Jeffrey B. Liebman. 2000. "The Taxation of Executive Compensation.” In Tax Policy and the Economy, vol. 14, edited by James Poterba. Cambridge, MA: MIT Press.

Hite, Gailen L., and Michael S. long. 1982. "Taxes and Executive Stock Options," Journal of Accounting and Economics (4): 3-14. 
Katuscák, Peter. 2005. "Impact of Personal Income Taxation on Executive Compensation." Working Paper, University of Michigan.

Levy, Frank S. and Peter Temir. 2007. "Inequality and Institutions in $20^{\text {th }}$ Century America," MIT Department of Economics Working Paper No. 07-17

Lewellen, Willbur G. 1968. Executive Compensation in Large Industrial Corporations. New York: National Bureau of Economic Research.

Lindsey, Lawrence. 1987. "Individual Taxpayer Response to Tax Cuts, 1982-1984, with Implications for the Revenue Maximizing Tax Rate." Journal of Public Economics 33: 173206.

Loss, Louis and Joel Seligman. 2003. Securities Regulation. Aspen Publishers, $3^{\text {rd }}$ Edition.

Madeo, S. and T. Omer. 1994. "The Effect of Taxes on Switching Stock Option Plans: Evidence from the Tax Reform Act of 1969," Journal of the American Taxation Association (16): 24-42.

McGahran, Kathleen T. 1988. "SEC Disclosure Regulation and Management Perquisites." The Accounting Review 63(1): 23-42

National Industrial Conference Board. 1953. Top Management Compensation. Studies in Labor Statistics, No. 8.

Patton, Arch. 1961. Men Money and Motivation. New York, NY: McGraw-Hill Book Company.

Piketty, Thomas and Emmanuel Saez. 2003. "Income Inequality in the United States: 19131998." Quarterly Journal of Economics 118: 1-39.

Rajan, Raghuram G and Julie Wulf. 2006. “Are Perks Purely Managerial Excess?,” Journal of Financial Economics 79: 1-33

Romer, Christina and David Romer. 2008. "A Narrative Analysis of Postwar Tax Changes." Working Paper.

Rose, Nancy L. and Catherine Wolfram. 2002. "Regulating Executive Pay: Using the Tax Code to Influence Chief Executive Officer Compensation." Journal of Labor Economics 20(2): S138-75.

Saez, Emmanuel. 1999. “The Effect of Marginal Tax Rates on Income: A Panel Study of 'Bracket Creep',' NBER Working Paper No. 7367 
Saez, Emmanuel. 2004. "Reported Incomes and Marginal Tax Rates, 1960-2000: Evidence and Policy Implications." In Tax Policy and the Economy 18, edited by James Poterba, Cambridge, MA: the MIT Press.

Scholes, Myron and Mark Wolfsen. 1992. Taxes and Business Strategy. Princeton, NJ: Prentice-Hall.

Slemrod, Joel B. 1992. "Do Taxes Matter? Lessons from the 1980s," American Economic Review 82: 250-256.

Slemrod, Joel B. 1996. "High-Income Families and the Tax Changes of the 1980s." In Empirical Foundations of Household Taxation, edited by Martin Feldstein and James Poterba. Chicago, IL: University of Chicago Press.

Slemrod, Joel B. 2000. "The Economics of Taxing the Rich.” In Does Atlas Shrug? The Economic Consequences of Taxing the Rich, edited by Joel B Slemrod, New York, NY: The Russell Sage Foundation.

Sundaram, Rangarajan K. and David Yermack. 2005. "Pay Me Later: Inside Debt and its Role in Managerial Compensation," NYU, Law and Economics Research Paper No. 05-08

United States Bureau of Economic Analysis. 1993. Survey of Current Business. August: p28.

Washington, George Thomas and V. Henry Rothschild. 1951. Compensating the Corporate Executive. New York: The Roland Press Company.

Yermack, David. 2006. "Flights of Fancy: Corporate Jets, CEO Perquisites, and Inferior Shareholder Returns," Journal of Financial Economics 80: 211-242 
Table 1

Summary Statistics

\begin{tabular}{|c|c|c|}
\hline & $\begin{array}{c}\text { Entire Sample } \\
(1946-2005)\end{array}$ & $1946-1972$ \\
\hline Observations & 21,776 & 9,287 \\
\hline Executives & 3,924 & 1570 \\
\hline Mean firms per year & 79 & 77 \\
\hline Mean executives per firm per year & 4.6 & 4.6 \\
\hline Mean observations per executive ${ }^{+}$ & 6.0 & 7.3 \\
\hline Mean salary+bonus ( $\$ 2000)$ & $\$ 969,394$ & $\$ 741,521$ \\
\hline Mean value of stock options granted $(\$ 2000)$ & $\$ 571,831$ & $\$ 62,697$ \\
\hline Mean value of long-term bonus pay & $\$ 312,526$ & $\$ 59,687$ \\
\hline Mean value of retirement bonuses ${ }^{++}$ & $\$ 63,333$ & $\$ 60,837$ \\
\hline Mean firm market value (billions of $\$ 2000$ ) & 16.2 & 8.88 \\
\hline Median firm market value (billions of $\$ 2000$ ) & 5.5 & 3.2 \\
\hline Mean firm rank by sales & 111 & 63 \\
\hline Median firm rank by sales & 61 & 41 \\
\hline
\end{tabular}

+ This value is the number of times each executive appears among the 5 highest paid in the firm in our entire dataset, not the number of times each individual executive is observed in a particular sample.

++ This average is for 1946-1991 only because we do not observe these grants after 1991.

Note. Sample based on the 5 highest-paid executives in the 50 largest firms in 1940, 1960, and 1990 (a total of 101 firms). Salary and bonus measured as the level of salaries and bonuses (paid out in either stock or cash) awarded and disbursed in the year. The value of stock options granted is measured using the Black-Scholes formula. Market value measured from CRSP at the end of the fiscal year. 
Table 2

Distribution of the Change in Ln(1-Marginal Labor Income Tax Rate)

\begin{tabular}{|c|c|c|c|c|c|c|}
\hline & \multicolumn{5}{|c|}{ Percentiles } & \multirow{2}{*}{$\begin{array}{l}\text { Standard } \\
\text { Deviation }\end{array}$} \\
\hline & 10th & 25 th & 50th & 75th & 90th & \\
\hline 1948 & 0.381 & 0.458 & 0.562 & 0.708 & 0.789 & 0.144 \\
\hline 1950 & -0.125 & -0.078 & -0.054 & -0.044 & -0.038 & 0.030 \\
\hline 1951 & -0.464 & -0.277 & -0.239 & -0.183 & -0.146 & 0.118 \\
\hline 1952 & -0.115 & -0.150 & -0.095 & -0.077 & -0.061 & 0.027 \\
\hline 1954 & 0.083 & 0.089 & 0.096 & 0.113 & 0.141 & 0.027 \\
\hline 1964 & 0.147 & 0.230 & 0.307 & 0.443 & 0.759 & 0.215 \\
\hline 1965 & 0.074 & 0.092 & 0.134 & 0.189 & 0.244 & 0.062 \\
\hline 1968 & -0.192 & -0.183 & -0.143 & -0.119 & -0.109 & 0.034 \\
\hline 1969 & -0.073 & -0.073 & -0.053 & -0.048 & -0.039 & 0.014 \\
\hline 1970 & 0.124 & 0.136 & 0.166 & 0.206 & 0.206 & 0.036 \\
\hline 1971 & 0.035 & 0.093 & 0.212 & 0.312 & 0.348 & 0.118 \\
\hline 1972 & 0.174 & 0.223 & 0.223 & 0.223 & 0.223 & 0.036 \\
\hline 1987 & 0.207 & 0.207 & 0.207 & 0.207 & 0.207 & 0.006 \\
\hline 1988 & 0.055 & 0.055 & 0.055 & 0.055 & 0.055 & 0.004 \\
\hline 1991 & 0.060 & 0.060 & 0.060 & 0.060 & 0.060 & 0.004 \\
\hline 1993 & -0.133 & -0.133 & -0.133 & -0.133 & -0.133 & 0.011 \\
\hline 2001 & 0.008 & 0.008 & 0.008 & 0.008 & 0.008 & 0.000 \\
\hline 2002 & 0.008 & 0.008 & 0.008 & 0.008 & 0.008 & 0.006 \\
\hline 2003 & 0.057 & 0.057 & 0.057 & 0.057 & 0.057 & 0.002 \\
\hline
\end{tabular}

Note. There is no change in marginal income tax rates in all other years. The 1982 reduction of the top marginal income tax rate from 70 to 50 percent does not appear in this table because the marginal tax rate on labor income had already been reduced to 50 percent by 1972 . 
Table 3

Changes in Ln(Salary+Bonus)

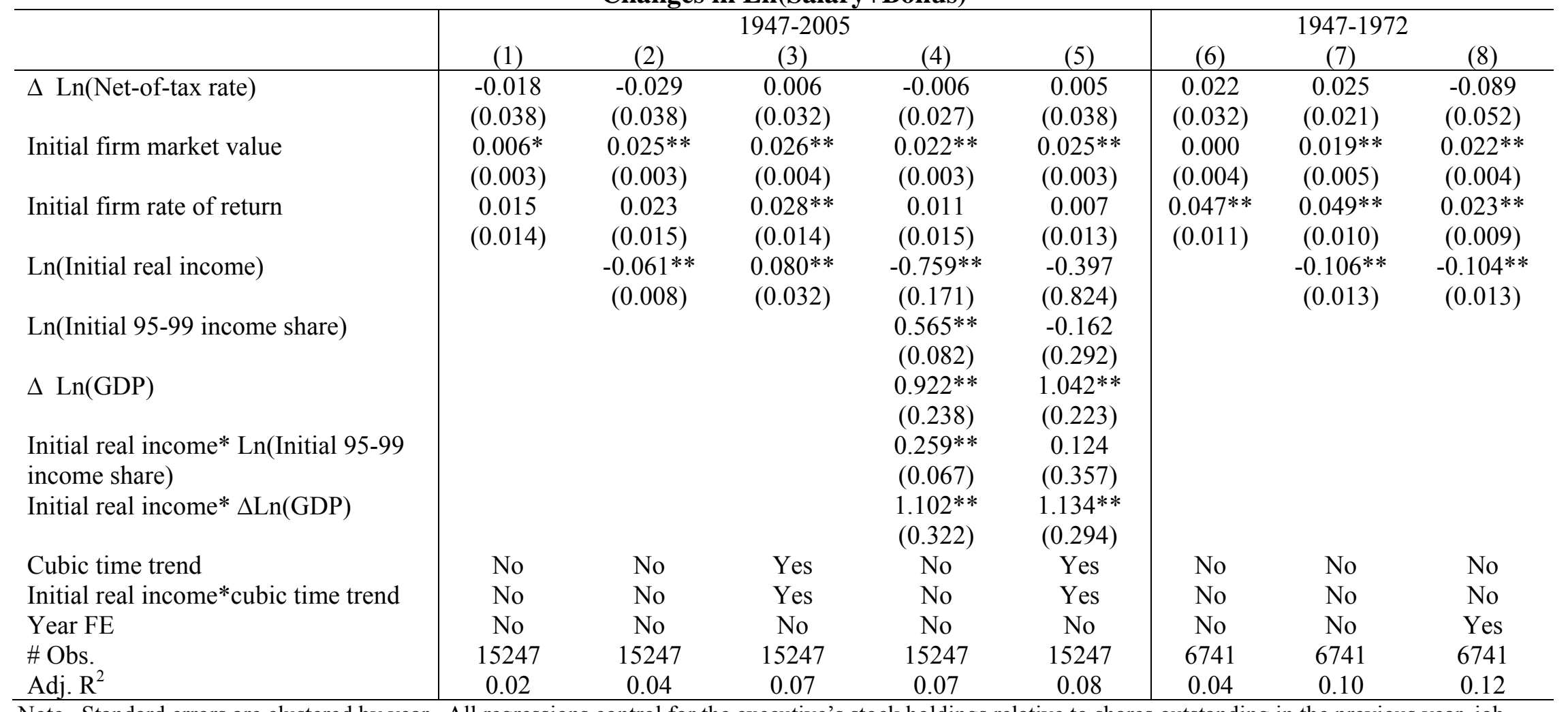

Note. Standard errors are clustered by year. All regressions control for the executive's stock holdings relative to shares outstanding in the previous year, job title in the previous year, director status in the previous year, and indicators for whether job title or director status changed from the previous to the current year. Real income is the executive's taxable income (salary+bonus+long-term incentive pay+exercised non-qualified stock options) deflated by the CPI. * and $* *$ indicate significance at the 10 percent and 5 percent levels, respectively. 


\section{Table 4}

Changes in Qualified Option Grants 1951-1975

\begin{tabular}{|c|c|c|c|c|}
\hline & \multicolumn{2}{|c|}{$\begin{array}{l}\text { Real Value of Grants } s_{t}- \\
\text { Real Value of Grants } \\
\text { (1) }\end{array}$} & \multicolumn{2}{|c|}{$\begin{array}{l}\text { Average Real Value of Grants } \mathrm{s}_{\mathrm{t}-2} \text { to } \mathrm{t} \\
\text { Average Real Value of Grants } \mathrm{t}_{\mathrm{t}-5} \text { to t-3} \\
\text { (3) }\end{array}$} \\
\hline$\Delta \operatorname{Ln}($ Net-of-tax rate $)$ & $\begin{array}{l}-0.015 \\
(0.032)\end{array}$ & $\begin{array}{c}-0.006 \\
(0.013)\end{array}$ & $\begin{array}{c}-0.023 \\
(0.025)\end{array}$ & $\begin{array}{c}-0.013 \\
(0.037)\end{array}$ \\
\hline Ln(Initial real income) & $\begin{array}{c}-0.003 \\
(0.008)\end{array}$ & $\begin{array}{l}-0.001 \\
(0.008)\end{array}$ & $\begin{array}{l}-0.002 \\
(0.012)\end{array}$ & $\begin{array}{l}-0.012 \\
(0.013)\end{array}$ \\
\hline Ln(Initial market value) & $\begin{array}{c}0.001 \\
(0.004)\end{array}$ & $\begin{array}{c}0.003 \\
(0.004)\end{array}$ & $\begin{array}{c}0.007 \\
(0.004)\end{array}$ & $\begin{array}{c}0.014^{* *} \\
(0.005)\end{array}$ \\
\hline Initial firm rate of return & $\begin{array}{c}0.033 * * \\
(0.013)\end{array}$ & $\begin{array}{c}0.004 \\
(0.013)\end{array}$ & $\begin{array}{c}0.038 * * \\
(0.011)\end{array}$ & $\begin{array}{c}0.028 * * \\
(0.010)\end{array}$ \\
\hline $\begin{array}{l}\text { Year FE } \\
\text { Sample period } \\
\text { \# Observations }\end{array}$ & $\begin{array}{l}\text { No } \\
1951-75 \\
6542\end{array}$ & $\begin{array}{c}\text { Yes } \\
1951-72 \\
5654\end{array}$ & $\begin{array}{c}\text { No } \\
1955-75 \\
2618\end{array}$ & $\begin{array}{c}\text { Yes } \\
1955-74 \\
2515\end{array}$ \\
\hline
\end{tabular}

Note. Standard errors are clustered by year. Real income is the executive's taxable income (salary+bonus+longterm incentive pay+exercised non-qualified stock options) deflated by the CPI. All regressions control for the executive's initial stock holdings relative to shares outstanding, initial job title, initial director status, and indicators for whether job title or director status changed from the initial year to the current year. Initial values are t-1 for columns 1-2 and $t-3$ for columns 3-4. The change in the net-of-tax rate is from $t-1$ to $t$ in columns 1-2 and from $t-3$ to $t$ in columns $3-4 . *$ and $* *$ indicate significance at the 10 percent and 5 percent levels, respectively.

\section{Table 5}

\section{Changes in Long-Term Bonus Payments}

\begin{tabular}{|c|c|c|c|c|c|c|}
\hline & \multicolumn{2}{|c|}{$\begin{array}{l}\text { Real Value of } \text { Payout }_{t}- \\
\text { Real Value of Payout } \\
t-2\end{array}$} & \multicolumn{2}{|c|}{$\begin{array}{l}\text { Real Value of Payout } \\
\text { Real Value of Payout } \\
\text { t-4 }\end{array}$} & \multicolumn{2}{|c|}{$\begin{array}{l}\text { Real Value of Payout } t_{t}- \\
\text { Real Value of Payout } t_{t-6} \\
\text { (5) }\end{array}$} \\
\hline \multirow[t]{2}{*}{$\Delta \operatorname{Ln}($ Net-of-tax rate) } & -0.001 & -0.031 & -0.018 & 0.081 & -0.053 & $0.059^{*}$ \\
\hline & $(0.027)$ & $(0.064)$ & $(0.029)$ & $(0.0$ & $(0.038)$ & $(0.032)$ \\
\hline \multirow[t]{2}{*}{ Ln(Initial real income) } & $0.040 * *$ & $0.023 *$ & -0.028 & 0.012 & -0.112 & 0.010 \\
\hline & $(0.015)$ & $(0.012)$ & $(0.017)$ & $(0.014)$ & $(0.081)$ & $(0.015)$ \\
\hline \multirow[t]{2}{*}{ Ln(Initial market value) } & $0.022 * *$ & $0.023 * *$ & $0.026^{* *}$ & $0.027 * *$ & $0.031 * *$ & $0.015 * *$ \\
\hline & $(0.003)$ & $(0.003)$ & $(0.005)$ & $(0.006)$ & $(0.008)$ & $(0.006)$ \\
\hline \multirow[t]{2}{*}{ Initial firm rate of return } & $0.047 * *$ & $0.030 * *$ & 0.018 & $0.034 *$ & 0.001 & $0.046 * *$ \\
\hline & $(0.017)$ & $(0.012)$ & $(0.024)$ & $(0.019)$ & $(0.025)$ & $(0.020)$ \\
\hline Year Fixed Effects & No & Yes & No & Yes & No & Yes \\
\hline Sample period & $1948-2005$ & $1948-1973$ & $1950-2005$ & $1950-1975$ & $1952-2005$ & $1952-1977$ \\
\hline \# Observations & 11563 & 5513 & 8007 & 4192 & 5455 & 3115 \\
\hline
\end{tabular}

Note. Standard errors are clustered by year. Real income is the executive's taxable income (salary+bonus+long-term incentive pay+exercised non-qualified stock options) deflated by the CPI. All regressions control for the executive's initial stock holdings relative to shares outstanding, initial job title, initial director status, and indicators for whether job title or director status changed from the initial year to the current year. Initial values are t-2 for columns 1-2, t-4 for columns 3-4, and $t-6$ for columns 5-6. The change in the net-of-tax rate is from $t-1$ to $t$ in columns $1-2$, from $t-4$ to $t$ in columns $3-4$, and from $\mathrm{t}-6$ to $\mathrm{t}$ in columns 5-6. ${ }^{*}$ and $* *$ indicate significance at the 10 percent and 5 percent levels, respectively. 


\section{Table 6}

\section{Correlation of Retirement Bonus Grants with Income Tax Rates}

\begin{tabular}{l|ccc|}
\hline & \multicolumn{3}{|c|}{ Real Value of Grants $\mathrm{fr}_{\mathrm{t}}-$} \\
& $(1)$ & $(2)$ & $(3)$ \\
\hline$\Delta$ Ln(Net-of-tax rate) & 0.008 & 0.006 & $0.015^{* *}$ \\
& $(0.005)$ & $(0.006)$ & $(0.006)$ \\
Ln(Initial real income) & 0.001 & 0.002 & 0.001 \\
& $(0.001)$ & $(0.001)$ & $(0.001)$ \\
Ln(Initial market value) & -0.001 & -0.000 & -0.000 \\
& $(0.000)$ & $(0.000)$ & $(0.001)$ \\
Initial firm rate of return & 0.001 & -0.001 & -0.003 \\
& $(0.002)$ & $(0.003)$ & $(0.004)$ \\
Year Fixed Effects & No & No & Yes \\
Sample period & $1947-91$ & $1947-72$ & $1947-72$ \\
\# Observations & 11361 & 6617 & 6617 \\
\hline
\end{tabular}

Note. Standard errors are clustered by year. Real income is the executive's taxable income (salary+bonus+long-term incentive pay+exercised non-qualified stock options) deflated by the CPI. All regressions control for the executive's initial stock holdings relative to shares outstanding, initial job title, initial director status, and indicators for whether job title or director status changed from the initial year to the current year. Initial values are the previous year and the change in the net-of-tax rate is from t- 1 to t. * and ** indicate significance at the 10 percent and 5 percent levels, respectively. 
Table 7

Changes in Ln(Taxable Labor Income)

\begin{tabular}{|c|c|c|c|c|c|c|c|c|}
\hline & \multicolumn{5}{|c|}{$1947-2005$} & \multicolumn{3}{|c|}{ 1947-1972 } \\
\hline & (1) & $(2)$ & (3) & (4) & $(5)$ & $(6)$ & $(7)$ & $(8)$ \\
\hline \multirow[t]{2}{*}{$\Delta \operatorname{Ln}($ Net-of-tax rate $)$} & -0.006 & -0.042 & 0.030 & 0.018 & 0.032 & 0.034 & $0.037 * *$ & -0.059 \\
\hline & $(0.041)$ & $(0.058)$ & $(0.033)$ & $(0.071)$ & $(0.036)$ & $(0.034)$ & $(0.016)$ & $(0.072)$ \\
\hline \multirow[t]{2}{*}{ Initial firm market value } & 0.009 & $0.074 * *$ & $0.075 * *$ & $0.063 * *$ & $0.075 * *$ & $0.010 * *$ & $0.027 * *$ & $0.031 * *$ \\
\hline & $(0.007)$ & $(0.009)$ & $(0.009)$ & $(0.009)$ & $(0.009)$ & $(0.004)$ & $(0.005)$ & $(0.005)$ \\
\hline \multirow[t]{2}{*}{ Initial firm rate of return } & $0.056 * *$ & $0.084 * *$ & $0.107 * *$ & $0.099 * *$ & $0.095 * *$ & $0.051 * *$ & $0.052 * *$ & $0.034 * *$ \\
\hline & $(0.023)$ & $(0.027)$ & $(0.022)$ & $(0.025)$ & $(0.023)$ & $(0.011)$ & $(0.011)$ & $(0.011)$ \\
\hline \multirow[t]{2}{*}{ Ln(Initial real income) } & & $-0.210 * *$ & $-0.131 * *$ & $0.605 *$ & 1.667 & & $-0.097 * *$ & $-0.097 * *$ \\
\hline & & $(0.025)$ & $(0.031)$ & $(0.306)$ & $(1.688)$ & & $(0.013)$ & $(0.013)$ \\
\hline \multirow[t]{2}{*}{ Ln(Initial 95-99 income share) } & & & & $1.433 * *$ & -0.035 & & & \\
\hline & & & & $(0.173)$ & $(0.542)$ & & & \\
\hline \multirow[t]{2}{*}{$\Delta \operatorname{Ln}(\mathrm{GDP})$} & & & & 0.534 & $0.903 * *$ & & & \\
\hline & & & & $(0.495)$ & $(0.364)$ & & & \\
\hline Initial real income* $\mathrm{Ln}$ (Initial 95-99 & & & & $-0.374 * *$ & -0.806 & & & \\
\hline income share) & & & & $(0.128)$ & $(0.740)$ & & & \\
\hline Initial real income $* \Delta \operatorname{Ln}(\mathrm{GDP})$ & & & & $1.544 * *$ & $1.678 * *$ & & & \\
\hline & & & & $(0.705)$ & $(0.650)$ & & & \\
\hline Cubic time trend & No & No & Yes & No & Yes & No & No & No \\
\hline Initial real income* cubic time trend & No & No & Yes & No & Yes & No & No & No \\
\hline Year FE & No & No & No & No & No & No & No & Yes \\
\hline \# Obs. & 15237 & 15237 & 15237 & 15237 & 15237 & 6741 & 6741 & 6741 \\
\hline
\end{tabular}

Note. Standard errors are clustered by year. All regressions control for the executive's stock holdings relative to shares outstanding in the previous year, job title in the previous year, director status in the previous year, and indicators for whether job title or director status changed from the previous to the current year. Real taxable labor income is (salary+bonus+long-term incentive pay+exercised non-qualified stock options) deflated by the CPI. * and ** indicate significance at the 10 percent and 5 percent levels, respectively. 
Table 8

Testing Explanations for the Lack of Correlation Between Taxes and Executive Pay

\begin{tabular}{|c|c|c|c|c|}
\hline & $\begin{array}{c}\Delta \operatorname{Ln}(\text { Salary }+ \\
\text { Bonus }) \\
(1947-1972) \\
(1) \\
\end{array}$ & $\begin{array}{c}\Delta \text { Stock Option } \\
\text { Grants } \\
(1951-1972) \\
(2) \\
\end{array}$ & $\begin{array}{l}\text { LT Bonus Pay }{ }_{t}- \\
\text { LT Bonus Payt-4 } \\
(1950-1975) \\
\text { (3) }\end{array}$ & $\begin{array}{c}\Delta \text { Retirement } \\
\text { Bonus Grants } \\
(1947-1972) \\
(4)\end{array}$ \\
\hline \multicolumn{5}{|c|}{ Panel A: Slow Evolution of Pay } \\
\hline Dependent variable $_{\mathrm{t}-1}$ & $\begin{array}{l}-0.058 \\
(0.054)\end{array}$ & $\begin{array}{c}-0.390 * * \\
(0.077)\end{array}$ & -- & $\begin{array}{c}-0.066^{* *} \\
(0.029)\end{array}$ \\
\hline Dependent variable $\mathrm{t}_{\mathrm{t}-2}$ & $\begin{array}{l}-0.007 \\
(0.020)\end{array}$ & $\begin{array}{c}-0.230 * * \\
(0.059)\end{array}$ & -- & $\begin{array}{l}-0.005 \\
(0.023)\end{array}$ \\
\hline Dependent variable $_{t-3}$ & $\begin{array}{c}0.005 \\
(0.026)\end{array}$ & $\begin{array}{c}-0.124 * * \\
(0.044)\end{array}$ & -- & $\begin{array}{l}-0.018^{*} \\
(0.010)\end{array}$ \\
\hline Dependent variable $\mathrm{t}_{\mathrm{t}-4}$ & -- & -- & $\begin{array}{c}0.549 * * \\
(0.055)\end{array}$ & -- \\
\hline$\Delta \operatorname{Ln}($ Net-of-tax rate $)$ & $\begin{array}{c}-0.113 * * \\
(0.054)\end{array}$ & $\begin{array}{c}0.023 \\
(0.030)\end{array}$ & $\begin{array}{l}0.053 * * \\
(0.022)\end{array}$ & $\begin{array}{c}0.011 \\
(0.009)\end{array}$ \\
\hline \multicolumn{5}{|c|}{ Panel B: Excluding Temporary Tax Reforms } \\
\hline$\Delta \mathrm{Ln}($ Net-of-tax rate $)$ & $\begin{array}{l}-0.079 \\
(0.057)\end{array}$ & $\begin{array}{c}0.007 \\
(0.020)\end{array}$ & $\begin{array}{l}0.164^{* *} \\
(0.051)\end{array}$ & $\begin{array}{c}0.016^{* *} \\
(0.016)\end{array}$ \\
\hline \multicolumn{5}{|c|}{ Panel C: Excluding Endogenous Tax Reforms } \\
\hline$\Delta \operatorname{Ln}($ Net-of-tax rate $)$ & $\begin{array}{l}-0.087 \\
(0.070)\end{array}$ & $\begin{array}{l}-0.008 \\
(0.014)\end{array}$ & $\begin{array}{c}0.205^{* *} \\
(0.046)\end{array}$ & $\begin{array}{l}0.014^{* *} \\
(0.007)\end{array}$ \\
\hline \multicolumn{5}{|c|}{ Panel D: Pay-to-Performance } \\
\hline$\Delta \mathrm{Ln}($ Net-of-tax rate $)$ & $\begin{array}{l}-0.084 \\
(0.050)\end{array}$ & $\begin{array}{l}-0.005 \\
(0.012)\end{array}$ & $\begin{array}{c}0.064 \\
(0.053)\end{array}$ & $\begin{array}{c}0.015 * * \\
(0.006)\end{array}$ \\
\hline $\begin{array}{l}\mathrm{Ln}(\text { increase in stock }+ \text { option } \\
\text { wealth for a } 1 \% \text { improvement } \\
\text { in firm performance) }\end{array}$ & $\begin{array}{c}0.001 \\
(0.002)\end{array}$ & $\begin{array}{c}-0.007 * * \\
(0.002)\end{array}$ & $\begin{array}{c}0.011 * * \\
(0.002)\end{array}$ & $\begin{array}{c}-0.001 \\
(0.0004)\end{array}$ \\
\hline \multicolumn{5}{|c|}{ Panel E: Within-Firm Equality } \\
\hline $\begin{array}{l}\Delta \text { Average compensation of } \\
\text { other top } 5 \text { executives }\end{array}$ & $\begin{array}{c}0.361 * * \\
(0.033)\end{array}$ & $\begin{array}{c}0.492 * * \\
(0.058)\end{array}$ & $\begin{array}{c}0.789 * * \\
(0.144)\end{array}$ & $\begin{array}{l}0.108 * * \\
(0.037)\end{array}$ \\
\hline$\Delta \mathrm{Ln}($ Net-of-tax rate) & $\begin{array}{l}-0.084 * \\
(0.048)\end{array}$ & $\begin{array}{l}-0.022 \\
(0.028)\end{array}$ & $\begin{array}{l}0.104 * * \\
(0.047)\end{array}$ & $\begin{array}{l}0.014^{*} \\
(0.007)\end{array}$ \\
\hline
\end{tabular}

Note. Standard errors are clustered by year. Each panel shows a separate regression with the dependent variable named in the column heading. All regressions include year fixed effects and control for the variables listed in Tables 3-6.

Regressions in Panel D also control for the contemporaneous rate of return and the contemporaneous change and lagged values of sales, assets, leverage, and market-to-book value. Temporary (1950, 1951, and 1968) and endogenous (the temporary reforms plus the reform in 1969) reforms are identified according to Romer and Romer (2008). Pay-toperformance is measured as the dollar increase in the previous year's stock and stock option holdings for a 1 percentage point increase in the firm's rate of return (Core and Guay 1999). * and ** indicate significance at the 10 percent and 5 percent levels, respectively. 


\section{Figure 1}

\section{Taxable Compensation and Labor Income Tax Rates}

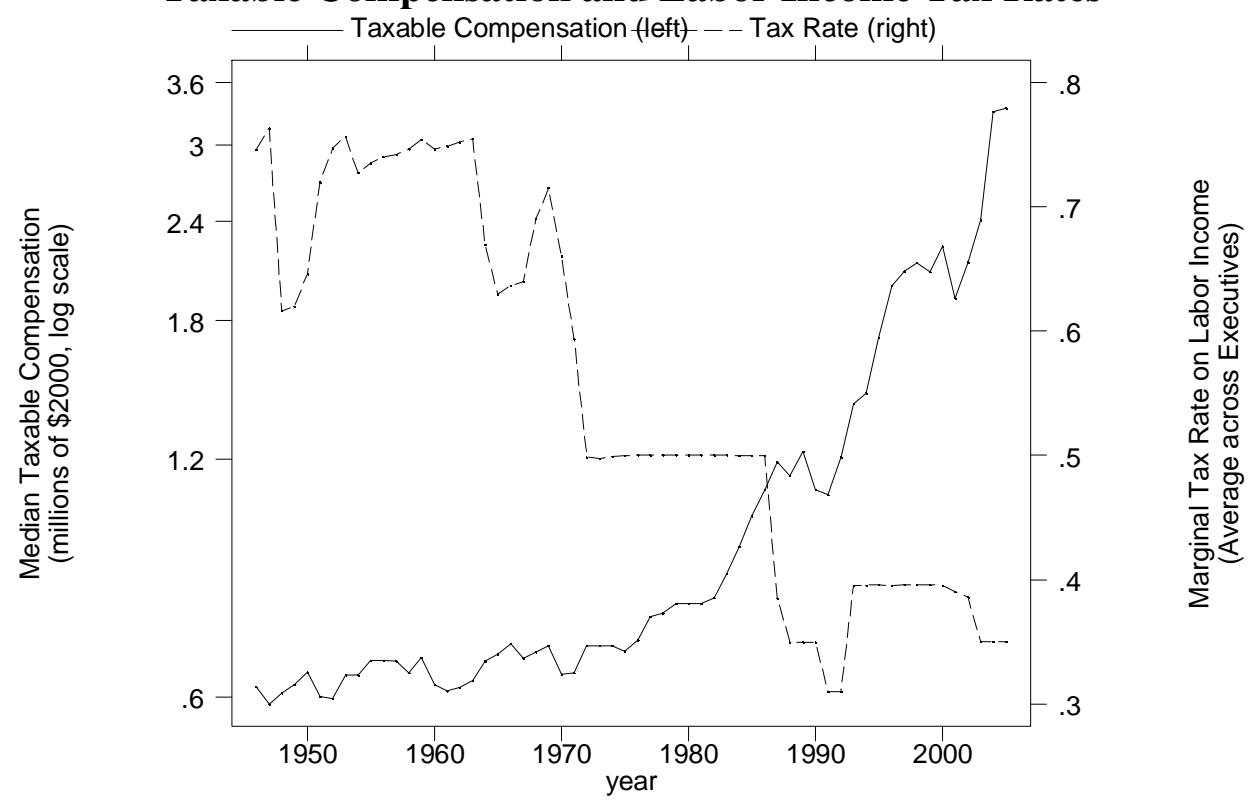

Note. Taxable compensation is the sum of salary, current bonus, long-term incentive payouts, and gains from exercised non-qualified stock options. The chart shows the median across executives. Marginal tax rates for each executive are calculated assuming that his reported labor income is equal to his taxable compensation and that he files jointly with a spouse.

Figure 2

\section{Tax Rates}

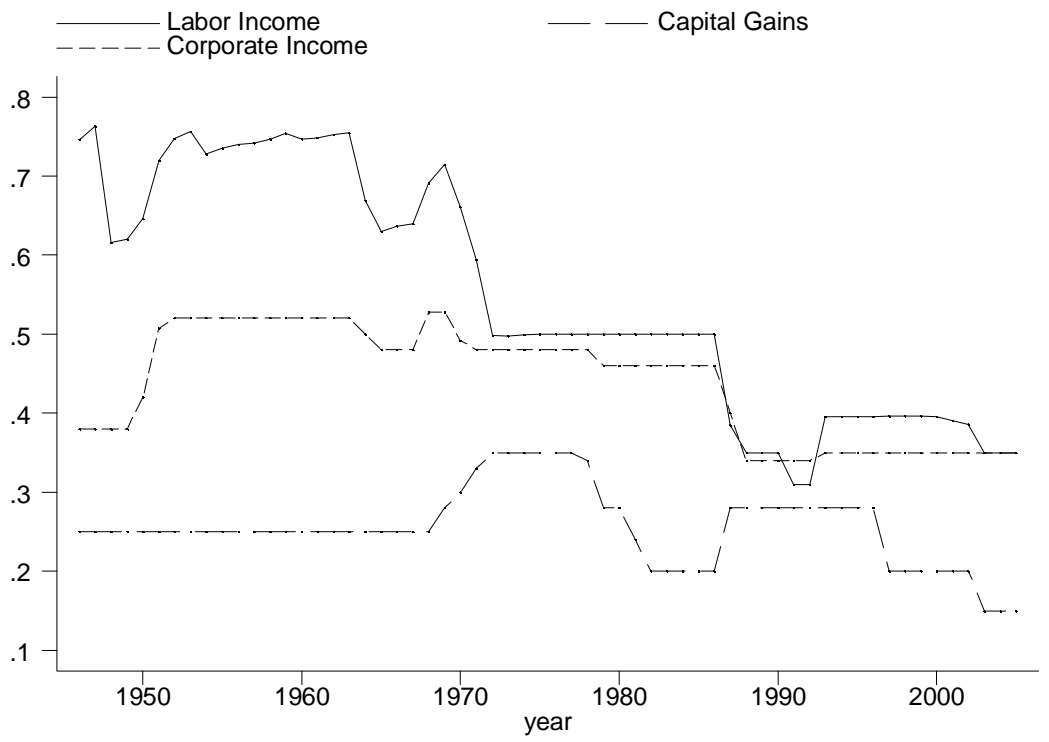

Note. The labor income tax rate is the marginal rate on labor income averaged across the executives in our sample. The rate for each executive is calculated assuming that his reported labor income is equal to his taxable compensation and that he files jointly with a spouse. The corporate income tax rate is the top marginal rate. 